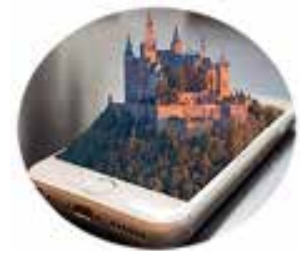

ЗБЕРЕЖЕННЯ КУЛЬТУРНОЇ СПАДЩИНИ

ТА ДОСТУП ДО ЦИФРОВИХ РЕСУРСІВ

SAVING CULTURAL HERITAGE AND ACCESS

TO DIGITAL RESOURCES

СОХРАНЕНИЕ КУЛЬТУРНОГО НАСЛЕДИЯ

И ДОСТУП К ЦИФРОВЫМ РЕСУРСАМ

UDC 004.9:316.343-054.5

DOI: 10.31866/2617-796x.2.1.2019.175654

Danieliene Renata,

PhD, Assoc. Professor Consultant, ECDL,

Director at the Information Technologies Institute,

Kaunas, Lithuania

renata.danieliene@gmail.com

https://orcid.org/0000-0003-3308-0919

\title{
Tolmach Marina,
}

lecturer of the Computer Sciences Department,

Kyiv National University of Culture and Arts,

Kyiv, Ukraine

margo.tolmach@gmail.com

https://orcid.org/0000-0002-7020-1348

\section{THE CITIZENS' DIGITAL COMPETENCIES AND THEIR ROLE IN THE MODERN LIFE}

The purpose of the article is to identify the basic digital competencies necessary for fullfledged communication and performance of official duties in the conditions of modern information technology development.

Research methods are the review and analyse of existing requirements for common specialists in different fields of activity, and the definition of the necessary skills and abilities for communication, performance of official duties, training.

The novelty of the conducted research is the information technology role definition for the society development and the active citizen in society.

Conclusion. Digital skills and competences are the basis of a modern person development who has been already in the digital world. The next step is to make this world a place where they can succeed.

Key words: information computer technologies; digital competence; knowledge; skills and abilities.

Introduction. The Ukraine development as a modern European state among other things involves the digital technologies development. The driving force of state development is human capital; they are knowledge, talents, skills, skills, experience, and

(c) Danieliene Renata

(C) Толмач М. С. 
intelligence. The rapid dissemination of digital technologies makes the citizens' digital competence key among other skills. Yes, digitalisation and cross-platform is at the moment the main trend in the overall labor market.

Research results. The workplaces number in Ukraine, requiring at least a basic understanding of information and communication technologies, is rapidly increasing. Due to the lack of accurate statistics, it is difficult to estimate this increase over the last decade, but objective reality shows that the ability to use digital technologies becomes the main requirement for staff.

The adaptation issues of society to rapidly changing technologies are currently relevant throughout the world, where each country is looking for ways to solve it. $90 \%$ of surveyed executives from all over the world (from 10,000 people in 140 countries) believe their company is facing devastating changes driven by digital technologies. $70 \%$ say their organization has no adaptation skills (Цифрова трансформація економіки в Україні, 2018).

Digital skills are the ability to use technology. It is reported not only about professional players in the information and computer technology field, but also about citizens in general, who can and should use technologies in everyday life. Technology has come not to compete with a person, but to help make it even more efficient and productive. In order for this tandem to be successful, a person must undergo a personal transformation, adapt to new realities and learn to live in them, using all their privileges.

There are many open source tools and resources available. A lot of high-quality, lowcost and free content offers us access to lifelong learning. With the help of YouTube tools and innovators, Han Academy, Udacity, Udemy, Coursera, NovoEd, edX, etc., new skills can often be obtained using a map-case, tablet or even a smartphone. The purpose of the state and business is to teach the society to use digital resources and to capitalize on acquired skills. Digital literacy is recognized by the EU as one of the eight key competences for high-quality life and activities in the modern world. In 2016, the EU introduced an updated Digital Competence Framework (DigComp 2.0), consisting of 21 competencies. There are skills in digital technologies, including Digital Quotient, that is, the ability to independently determine the need for additional new digital skills.

It should be noted that digital maturity goes far beyond the technology - a matter of synchronizing talent, culture and organizational structure with the digital environment. It should be noted that digital maturity goes far beyond the technology; there is a question of synchronization of talent, culture and organizational structure with the digital environment. Deloitte's research in the UK shows that future workforce needs a balance of technical skills and common abilities, such as problem solving, creativity, social skills and emotional intelligence (Цифрова трансформація економіки в Україні, 2018).

For Ukraine, modern digital skills training are no longer news, we have a number of successful private projects that can and should go to the state level, become massive, form the basis of formal education and have state support. A striking example of such projects is the Academy "Krok», Unit Factory, Main Academy and many others. The state-sponsored state-of-the-art provider of educational services could help increase private investment in this segment and the emergence of new operators. And also, in the short term, it will significantly increase the ability of commercial providers 
to service a much larger number of citizens, create new curricula, make them accessible both physically and financially.

The Qualification Report of the Professionals in the Digital World (Kiss, 2017), the Organization for Economic Co-operation and Development (OECD) identifies four types of ICT-related skills that are needed by a modern specialist in the workplace. These include: access to information on the Internet or through specialized software; skills needed to create products and services related to information technology (for example, programming, application development, network management, etc.); skills related to information processing, problem solving and communication; digital literacy, skills that allow the use of digital technology.

To ensure a sufficient level of digital competence with educators, civil servants and other categories of the population, appropriate requirements and conditions must be created at the state level.

One of the first such documents was the order of the Cabinet of Ministers of Ukraine dated January 17, 2018 No. 67-r "Concept of the Digital Economy Development and Society of Ukraine for 2018-2020", which outlined more concrete steps towards the system development for increasing the digital literacy of the Ukrainian population: making changes to the register of professions and developing a program for introducing digital specialties into the corresponding curricula of specialized educational institutions; the project evolution on the development of citizens' digital skills and modernization of pre-school, general secondary, extra-curricular, vocational (vocational), higher education and adult education systems, including taking into account models of public-private partnership and creating appropriate incentives for the non-formal education development.

An important role in the digital competences development of Ukrainian citizens was played by the document Digital Aidheny of Ukraine 2020, which explained the concept of "digital competence", identifies the European approach to the development of this segment as a priority and contains a list of steps to build a digital literacy and skills development system in Ukraine. Digital competence includes not only digital skills but a set of skills, knowledge, views on the nature and role of information technology and the opportunities that they offer in everyday situations, as well as relevant legal and ethical principles.

The basis of digital competence is the skills of using digital technologies, communication tools, management, integration, evaluation, and creation and information transmission.

Digital competence includes skills in the digital information and communication environment, understanding and critical assessment of digital and media content, effective and safe use of digital technologies for solving various professional tasks.

Conclusion. The field of digital skills and competences in Ukraine is developing chaotically and separately from formal education. The massive and extensive formal education system currently does not fully meet the labor market needs. A key decision is the combined strategy, which has long-term measures and scale, inherent in the state education system, and short-term quick measures that are more relevant for realization in the commercial education segment. 


\section{СПИСОК ПОСИЛАНЬ}

Цифрова трансформація економіки в Україні, 2018. [online] Доступно: <https://www2. deloitte.com/ua/uk/pages/press-room/press-release/2018/digital-transformation-ofukrainian-economics.html> [Дата звернення 18 квітня 2019].

3D Mapping of Ukrainian Education System. [online] Available at: <http://moped.kubg.edu.ua/ wpcontent/uploads/2014/03/MoPED_D1.23DMapping.pdf> [Accessed 18 April 2019].

Kiss, M., 2017. Digital skills in the EU labour market. European Parliamentary Research Service. doi:10.2861/451320.

\section{REFERENCES}

3D Mapping of Ukrainian Education System. [online] Available at: <http://moped.kubg.edu.ua/ wp-content/uploads/2014/03/MoPED_D1.2-3DMapping.pdf> [Accessed 18 April 2019].

Kiss, M., 2017. Digital skills in the EU labour market. European Parliamentary Research Service. doi:10.2861/451320.

Tsyfrova transformatsiia ekonomiky $v$ Ukraini [Digital transformation of economy in Ukraine]. [online] Available at: https://www2.deloitte.com/ua/uk/pages/press-room/pressrelease/2018/digital-transformation-of-ukrainian-economics.html [Accessed 18 April 2019].

\section{Удк 004.9:316.343-054.5}

\section{Даніліне Рената,}

PhD, доцент Каунаського факультету Вільнюського університету, директор Інституту інформачійних технологій,

Каунас, Литва

renata.danieliene@gmail.com

https://orcid.org/0000-0003-3308-0919

\section{Толмач Марина,}

викладач кафедри комп'ютерних наук,

Київський національний університет культури і мистецтв,

Київ, Україна

margo.tolmach@gmail.com

https://orcid.org/0000-0002-7020-1348

\section{ЦИФРОВІ КОМПЕТЕНЦІЇ ГРОМАДЯН ТА ЇХ РОЛЬ В СУЧАСНОМУ ЖИТТІ}

Метою статті $€$ визначення основних цифрових компетенцій необхідних для повноцінного спілкування та виконання службових обов'язків в умовах сучасного розвитку інформаційних технологій.

Методами дослідження $€$ огляд та наліз існуючих вимог до сучаних спеціалістів різних сфер діялності, та визначення необхідних вмінь та навичок для здійснення комунікацій, виконання службових обов'язків, навчання. 
Новизною проведеного дослідження $€$ визначення ролі інформаційних комп'ютерних технологій для розвитку суспільства та окермого громадянина в суспільстві.

Висновок. Цифрові навички та компетенції - основа розвитку сучасної людини, яка вже перебуває у цифровому світі. Наступний крок - зробити так, щоб цей світ став місцем, де вони зможуть стати успішними.

Ключові слова: інформаційні комп'ютерні технології; цифрові компетентності; знання; вміння; навички.

\section{Удк 004.9:316.343-054.5}

Данилине Рената, PhD, доцент Каунасского факультета Вильнюсского университета, директор Института информационных технологий, Каунас, Литва renata.danieliene@gmail.com

https://orcid.org/0000-0003-3308-0919

\section{Толмач Марина,}

преподаватель кафедры компьютерных наук, Киевский национальный университет культуры и искусств, Киев, Украина margo.tolmach@gmail.com https://orcid.org/0000-0002-7020-1348

\section{ЦИФРОВЫЕ КОМПЕТЕНЦИИ ГРАЖДАН И ИХ РОЛЬ В СОВРЕМЕННОЙ ЖИЗНИ}

Целью статьи является определение основных цифровых компетенций необходимых для полноценного общения и выполнения служебных обязанностей в условиях современного развития информационных технологий.

Методами исследования являются обзор и нализ существующих требований к Сучане специалистов различных сфер диялности, и определение необходимых умений и навыков для осуществления коммуникаций, выполнение служебных обязанностей, обучения.

Новизной проведенного исследования является определение роли информационных компьютерных технологий для развития общества и окермого гражданина в обществе.

Вывод. Цифровые навыки и компетенции - основа развития современного человека, который уже находится в цифровом мире. Следующий шаг - сделать так, чтобы этот мир стал местом, где они смогут стать успешными.

Ключевые слова: информационные компьютерные технологии; цифровые компетентности; знания; умения; навыки. 